\title{
A Tetrahydruisoquinoline Derivative Isolated from the Acetone Extract of Dioscorea batatas ${ }^{\dagger}$
}

\author{
By Tetsuzo Tono \\ Department of Agricultural Chemistry, Faculty of Agriculture, \\ Tottori University, Tottori \\ Received August 1, 1970
}

As described in the previous paper on polyphenols in the chinese yam (Dioscorea batatas Decne), dopamine and a new phenolic amine were obtained from the acetone extract of aerial tubers from a yam, the so-called "Mukago"." However, the latter phenolic amine obtained remained impure. Thus, the characterization of this phenolic amine, which has now been obtained in a chromatographically pure state is described in this paper.

Aerial tubers of yam $(2 \mathrm{~kg})$ were extracted with $70 \%$ acetone at $75^{\circ} \mathrm{C}$ for $2 \mathrm{hr}$. Extraction was repeated more than three times and each extract was gathered. The two phenolic amines were isolated from this acetone extract as follows. After the extract was dried in vacuo, distilled water was added to the residue and the mixture was filtered. The aqueous filtrate was chromatographed on Amberlite CG 120 resin, followed by successive elutions with $0.1 \mathrm{M}$ phosphate buffer $(\mathrm{pH} 7)$ and $3 \mathrm{~N}$ hydrochloric acid. The acid effluent was concentrated to a syrup in vacuo and its precipitate was filtered out. In the filtrate, two compounds were detected with paper chromatography (n-butanol-acetic acid-water, $4: 1: 2$, $\mathrm{v} / \mathrm{v}$; spray, ethanolic ferric chloride and

$\uparrow$ Studies on the Pictet-Spengler Reaction of Catecholamine with Acetone. Part I. (A part of this work was presented at Annual Meeting of the Agricultural Chemical Society of Japan, held at Fukuoka, Japan, on April 4, 1970.)

1) T. Tono, Bull. Fac. Agr. Tottori Univ. Japan, 22, $13(1970)$. ninhydrin), showing distinct spots at $R f 0.50$ and 0.62 , respectively. To separate the two compounds, the filtrate was rechromatographed on Amberlite CG 50 resin, followed by successive elutions with water and $0.1 \mathrm{~N}$ hydrochloric acid. Each effluent was concentrated to a syrup in vacuo, to which was added a drop of conc. hydrochloric acid. Crystalline salts were obtained. Repeated recrystallization from ethanol afforded colorless prisms (A: from water fraction, yield of about $0.13 \mathrm{~g}$; B: from $0.1 \mathrm{~N}$ hydrochloric acid fraction, yield of about $0.5 \mathrm{~g}$ ).

A was identified with authentic dopamine hydrochloride (I) by comparing their mp, $R f$ values, and UV and IR spectra, as reported in the previous paper.

$B$ showed the following properties. An aqueous solution of $\mathrm{B}$ gave a dark green color with ferric chloride, a milky white one with basic lead acetate and a reddish violet one with ninhydrin. The substance was, to some extent, oxidized by the action of polyphenol oxidase prepared from the yam tubers. Thus, $B$ should have the character of both an 0 diphenol and an amine. It was readily soluble in water, methanol and ethanol, and was insoluble in acetone, ethyl ether and chloroform. Rf 0.62 for the same paper chromatography as above, $m p 265^{\circ} \mathrm{C}$, Anal. Found: C, 57.41; $\mathrm{H}, 7.06 ; \mathrm{N}, 6.09$; Cl, 15.17, M.W. 229.5 (free base 193 from mass spectrometry), Calcd. for $\mathrm{C}_{11} \mathrm{H}_{15} \mathrm{NO}_{2} \cdot \mathrm{HCl}: \quad \mathrm{C}, 57.52 ; \mathrm{H}, 6.95 ; \mathrm{N}, 6.10$; Cl, 15.47, M.W. 229.5. UV $\lambda_{\max }^{\mathrm{EtOH}} \mathrm{m} \mu: 286$ (a bathochromic shift of the $\lambda_{\max }$ was observed 


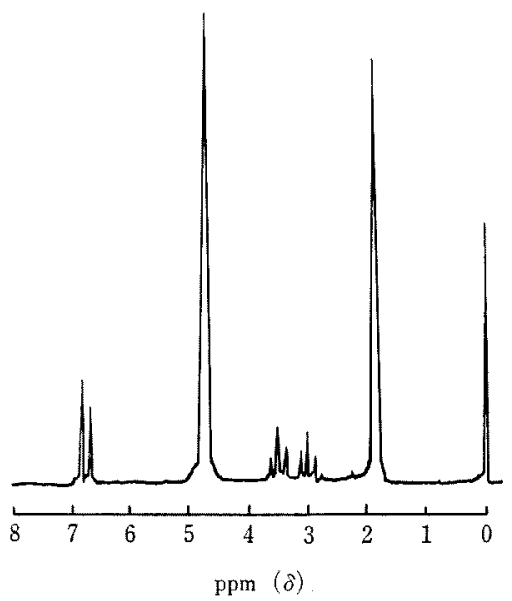

FIG. 1. NMR Spectrum of $\mathrm{B}$ in $\mathrm{D}_{2} \mathrm{O}(60 \mathrm{Mc})$.

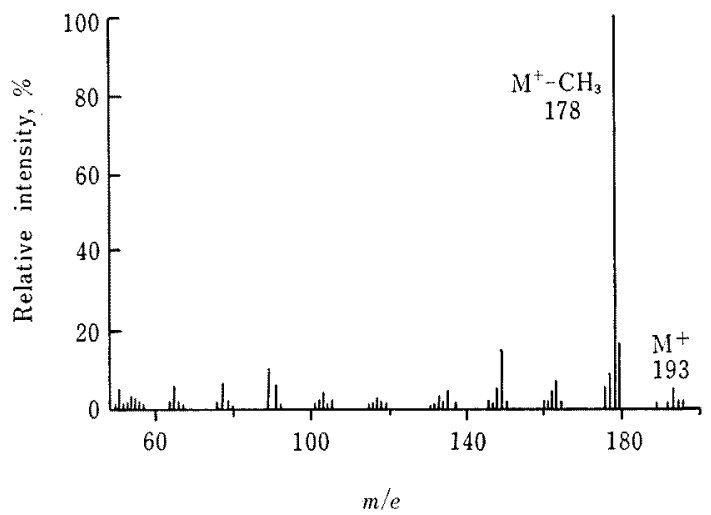

FIG. 2. Mass Spectrum of $\mathrm{B}$.

Conditions: $75 \mathrm{eV}, 150^{\circ} \mathrm{C}, 200 \mu \mathrm{A}$

in $0.1 \mathrm{~N} \mathrm{NaOH}$ solution). IR $\nu_{\max }^{\mathrm{KBr}} \mathrm{cm}^{-1}$ : near 1200 and 3350 (phenolic $\mathrm{OH}$ ), $3200(\mathrm{NH}), 1450$ and near $2900\left(\mathrm{CH}_{3}\right.$ or $\left.-\mathrm{CH}_{2}-\right), 1530$ and near 1600 , etc. NMR $\delta$ ppm in $\mathrm{D}_{2} \mathrm{O}$ : $1.70\left(6 \mathrm{H}\right.$, singlet, $\left.\mathrm{C}_{\mathrm{CH}_{3}}^{\mathrm{CH}_{3}}\right), 2.98$ and 3.50 (each $2 \mathrm{H}$, triplet, $J=6 \mathrm{cps},-\mathrm{CH}_{2}-\mathrm{CH}_{2}-$ ), 6.71 and 6.83 (each $1 \mathrm{H}$, singlet, aromatic protons). (See Fig. 1). It's mass spectrum showed a molecular ion $\left[\mathrm{M}^{+}\right.$(free base), m/e: 193] and a base peak $\left(\mathrm{M}^{+}-\mathrm{CH}_{3}, m / e\right.$ : 178$)$ with an extremely high intensity. (See Fig. 2). Furthermore, acetylation of $B$, in the usual way, gave a triacetate $\ldots \mathrm{mp} 145.5^{\circ} \mathrm{C}$; NMR $\delta \mathrm{ppm}$ in $\mathrm{CDCl}_{3}: 2.18\left(3 \mathrm{H}\right.$, singlet, $\left.\mathrm{N}-\mathrm{COCH}_{3}\right), 2.28$ $\left(6 \mathrm{H}\right.$, singlet $\left.2 \cdot \mathrm{O}-\mathrm{COCH}_{3}\right)$. NMR data on the acetate indicated that the $\mathrm{NH}$ and $2 \mathrm{OH}$ in $\mathrm{B}$ were acetylated. From the especially high intensity of base ion (m/e: 178), from the downfield shifts of methyl and methylene protons in the NMR data on B and from other results, structure II was proposed for B.<smiles>CCc1cc(O)c(O)cc1C(C)(C)NCl</smiles>

(II)

Isoquinoline alkaloids with relatively simple structures as in the above compound, have been found in some natural plants, ${ }^{21}$ while Schöpf et $a l .^{3)}$ reported that under certain physiological conditions, isoquinoline derivatives could be produced with the PictetSpengler condensation reaction between catecholamine and formaldehyde. In addition, the same compound as B was obtained from an acetone extract of banana skin which contained dopamine. ${ }^{4)}$ However, no isoquinoline could be detected from the methanol or aqueous extracts of both yam tuber and banana skin. ${ }^{51}$ Recently, I also found that a compound the same as B is formed, in a yield of more than $60 \%$, from dopamine hydrochloride in $50 \%$ acetone at $25^{\circ} \mathrm{C}$ for a week. Further qualification of the formation mechanism of isoquinoline derivatives from dopamine and acetone, is on the way, and will be reported

2) T. Kametani, "The Chemistry of the Isoquinoline Alkaloids," Hirokawa Publishing Co., Tokyo, 1968, pp. $25 \sim 30$.

3) C. Schöpf and H. Bayerle, Ann., 513, 190 (1934).

4) L. A. Griffiths, Nature, 184, 58 (1959).

5) T. Tono, Nippon Shokuhin-Kogyo Gakkaishi, 17, 447 (1970), from the survey from methanol extract of chinese yam, the other results are unpublished. 
later. Therefore, it is likely that the present isoquinoline derivative obtained from the acetone extract of chinese yam may be formed from a condensation reaction between dopamine and acetone.

Thanks are due to Prof. T. Ito and Assistan Prof. T. Hamasaki of this university, for their valuable discussion of this work. I am also indebted to Dr. I. Ichimoto, University of Osaka Prefecture, for elemental analysis, to Mr. Y. Ikebe, Hitachi Co. Ltd., for measuring the NMR spectrum, and to Mr. T. Nimi for the experimental assistance be rendered to this study. 